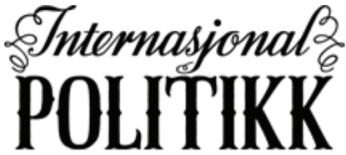

SKANDINAVISK TIDSSKRIFT

FOR INTERNASJONALE STUDIER

Årgang 78, Nummer 3, side 358-361, 2020, ISSN 1891-1757, www.tidsskriftet-ip.no, Publisert november 2020

\section{Libya: Krigens uutholdelige letthet}

Tormod Heier, Rune Ottosen \& Terje Tvedt (red.)

Oslo, Cappelen Damm Akademisk (2019)

Anmeldt av advokat Ola Tellesbø

Antologien er på 252 sider og har elleve bidragsytere. Først ut er Terje Tvedt.

Ine Marie Eriksen Søreide sa i 2019 at i "Libya var målsettingen med de militære operasjonene å beskytte sivile[...] ikke regimeendring». "Hvordan er det mulig, gitt det alle nå vet», spør Tvedt (s. 39). «Norges rolle i krigen ble jo nettopp å knuse Gaddafis hær» (s. 40). Tvedt skriver om «situasjonen» som aldri forandret seg, som om den libyske hæren alltid truet sivilbefolkningen aldri så mye empirien tidlig fastslo det motsatte, aldri så mye hærens opptrapping mot Benghazi var stoppet, aldri så mye hæren var slått tilbake. Dermed var ifølge Søreide «handlingssituasjonen» den samme.

I underkapitlet «Når krig blir mer juss enn politikk» (s. 35) går Tvedt mot rettsliggjøring av debatten om krigens konsekvens. Hvorfor det? Jussen mer enn noe annet viser at de to mest nærliggende krigsforbrytelsene er forbigått i stillhet. Det som derimot har frikjent Stoltenberg II-regjeringen, mer enn noe annet, var Solberg-regjeringens subtile innsnevring av mandatet til Libya-utvalget:

Utvalget skal evaluere den nasjonale beslutningsprosessen og beslutningsgrunnlaget for Norges bidrag til og senere avvikling av deltakelse i Odyssey Dawn og OUP innenfor de tidskritiske rammer utviklingen $i$ Libya og den internasjonale reaksjonen satte.

Utvalget avgrenset på denne bakgrunnen mandatet «i tid fra mars 2011 til og med august 2011 da det norske jagerflybidraget avsluttet sitt oppdrag» (Libya-utvalgets

(C2020 Ola Tellesbø. This is an Open Access article distributed under the terms of the Creative Commons Attribution 4.0 International License (http://creativecommons.org/licenses/by/4.0/), allowing third parties to copy and redistribute the material in any medium or format and to remix, transform, and build upon the material for any purpose, even commercially, provided the original work is properly cited and states its license.

Citation: Tellesbø, O. (2020). Libya: Krigens uutholdelige letthet. Internasjonal Politikk, 78(3): 358-361. http://dx.doi. org/10.23865/intpol.v78.2346 
rapport s. 18), som var 1. august 2011. Men Stortinget forutsatte at «etter Afghanistanutvalgets rapport er [det] naturlig at det også gjennomføres en evaluering av Norges sivile og militære rolle $i$ forkant av, under og etter Libya-operasjonen i 2011" (min utheving) og vedtok, jf. Innst. 248 S (2016-2017), følgende: «Stortinget ber regjeringen ta initiativ til å gjennomføre en evaluering $\mathrm{i}$ egnet form av den norske militære og sivile deltakelsen i operasjonen i Libya i 2011.»

Utvalget snevret inn videre. Utvalget skulle "vurdere et norsk bidrag i en internasjonal koalisjon. Dermed vil flere aspekter ved koalisjonen og NATOs gjennomføring falle utenfor dette utvalgets undersøkelser» (s. 16, min utheving). Slik unngikk utvalget å undersøke om norsk militær deltakelse kan ha medvirket til krigsforbrytelser.

Den ene mulige medvirkningen til krigsforbrytelse er tilskyndelsen av drapene på mørkhudede fremmedarbeidere. Den andre er at etter 1. august 2011 er det rapportert flest sivile drepte som følge av Natos bomber. Norge bidro etter 1. august med å plukke ut bombemål. Målene ble mer og mer tvilsomme. Av de seks bombeangrepene med sivile drepte som FNs International Commission of Inquiry undersøkte, var fire etter 1. august (avsnittene 619-648). To kjente bombinger av sivile ble ikke undersøkt på grunn av tids- og sikkerhetsbegrensninger (avsnittene 607). Paal Henriksrud lot i Militere Studier 3 (2014, s. 78-79) en norsk offiser fortelle om bombingen:

\begin{abstract}
Diskusjonen gikk på hvis man for eksempel hadde et mål som ikke var en imminent threat mot noe som helst. Det kunne være bygninger, forlatte APCer eller what not, uten at de på en måte var en trussel mot noen, hadde ikke skutt på noen, de var der bare i, hva skal jeg si, i effekt av å bare være. Så definerte man ofte bygninger til å være C2-noder, ammunisjonslagre, rally points osv, og de kunne da tas ut innenfor det rette collateral damage-nivået osv. Vi diskuterte mange ganger: gir resolusjonen åpning for det vi gjør nå? Og det var vel noen spørsmål som vi på en måte ikke besvarte. Kanskje med en antagelse om at vi visste hva svaret var, som ikke nødvendigvis politisk ville tåle dagens lys. [...] Helt ærlig, jeg var med og gjorde ting, og var med å ta avgjørelser og planla ting, som jeg tror ikke hadde blitt godkjent av en norsk Red Card Holder for bruk av norske fly.
\end{abstract}

To bidragsytere skriver om den politiske ledelsens ansvar, men forut for 1. august. Anne Karin Larssen påpeker at selv om norsk politisk ledelse deltok i Nato-rådet, manglet det politisk vilje ned mot det taktiske nivået der det norske militæret bidro. «I Libya-krigen fikk ikke norske styrker caveats» (s. 114). Caveats kan være begrensninger på hvilke mål norske fly har lov til å bombe eller krav om politisk godkjenning forut for bombing av visse typer mål. Manglende styring hvis noe galt skjer, er også en forbrytelse, jf. straffelovens $₫ 109$ (Roma-vedtektene, art. 28).

Tormod Heier skriver om kontroll i betydningen å definere og fremme egne nasjonale interesser. Norges realpolitiske interesse som småstat er å ha en fungerende internasjonal orden. Dette bidro ikke Norge til. Dernest betyr kontroll å være seg bevisst på forskjellen mellom venner og allierte. Å ha kontroll er å øve press på allierte 
for å styre maktbruken inn på spor som ellers ikke ville ha blitt valgt - altså evnen til å få andre til å gjøre noe de ellers ikke ville ha gjort - slik at de norske interessene blir ivaretatt. Heier avslutter med at det vi har lært, er statsforvaltningens «sterke uvilje mot å ta ansvar i krig» (s. 86). Til tross for det bevisste valget om ikke å ha norsk personell i Natos operasjonelle hovedkvarter konkluderte Libya-utvalget med at kontrollen var god. Det får Heier til å spørre om utvalgets habilitet og uavhengighet.

Libya-utvalget tildekket også den norske feilbombingen av Gaddafis palass 25. april (Libya-utvalgets rapport s. 104), hvorpå tre sivile ble drept. Det var ikke militære installasjoner i nærheten av bombenedslaget, ifølge NRKs dokumentar De gode bombene (2013). Rune Ottosen skriver at da Petersen ble tatt for å skjule feilbombingen med tap av sivile, svarte han (s. 141): «Jeg liker ikke spørsmålet ditt. Vi bombet militære mål.»

Ottosen påpeker at utvalget erkjente at såkalte advarsler om angrep på sivilbefolkningen ble akseptert uten kritisk blikk, og at det «kan ha bidratt til å hausse opp trusselbildet». «Det merkelige er at denne erkjennelsen ikke får konsekvenser for konklusjonen til Libya-utvalget» (s. 128). Ottosen finner det oppsiktsvekkende at utvalget ikke har forholdt seg til dokumentasjon som har kommet i ettertid. Hvis utvalget var uenig med den britiske evalueringen om at trusselen var oppkonstruert, burde utvalget vel i det minste ha argumentert mot den, spør Ottosen.

Minda Holm kommenterer i sitt bidrag den norske unnfallenheten (s. 59):

Én ting er at det eksisterer en åpenbar dobbeltmoral. Vissheten om den er så naturalisert at det tilsynelatende har liten politisk effekt å påpeke den. Samtidig eksisterer det en manglende vilje til å erkjenne hvordan egne handlinger selv kan ha bidratt til å undergrave det liberale prosjektet man parallelt promoterer.

Holm skriver at norske utenriksministre kontinuerlig har lagt vekt på verdifellesskapet mellom USA og Norge. Hun fortsetter (s. 59):

Det åpenbart paradoksale er dermed at Norge har knyttet seg i verdifellesskap med det landet som også i størst grad har misbrukt sin makt til å bryte viktige prinsipper i folkeretten. Men, fordi USA sees på som «iboende» god, ser det ikke ut til at handlingene får konsekvenser for norsk offisielt syn på landet som verdiforkjemper.

Dette er kanskje det mest skremmende. Heier skriver at det er åpenbart at krigen slo feil. Men ut fra hvilken målestokk? Hensyntatt det liberale prosjektet med ideen om USA som garantist er det ikke bare sannsynlig at feilen gjentas, men at feilen ikke kalles feil. For de som raderte bort Afrikas best fungerende stat på Human Development Index, er det umulig å mene at operasjonen slo feil. De vil være overbevist om rettmessigheten av krigen resten av tiden som politikere. Ingen ting påvirker oss mer enn våre handlinger, særlig hvis de får konsekvenser. Det er dette som ligger i det ekvilibrium som søkes for å unngå kognitiv dissonans, altså holdningsendring i tråd med egne handlinger for å komme bort fra kvalene over å ha gjort urett. Kognitiv dissonans får en dobbeleffekt når vi vet at ekvilibrium også oppnås, slik Holm påpeker, ved å stenge 
ute informasjonen «som ikke stemmer med vår virkelighetsoppfatning» (s. 63). Det som kalles kognitiv dissonans forklarer altså hvordan våre holdninger sedimenteres både i forkant og i etterkant av våre handlinger.

Styresmaktene unndrar seg kritikk for ikke å vite det som var lett å vite, og som må forutsettes kjent for å gå til krig. Det var aldri et spørsmål om kunnskap eller mangel på kunnskap, men om viljen til å krige - uten kunnskap. Berit von der Lippe forklarer at det handler om «spesifikke måter å se verden på - relatert til ulike interesser og makt» (s. 197). En hendelse må ikke «ha funnet sted, for at enkelte likevel opplever dets nærvær». Dette er en god beskrivelse av Stoltenberg, Støre og Lysbakken. For dem forelå det nok kunnskap innenfor egen selvforståelse.

Larssen redegjør for forståelsen av «Norge som en god alliert» (s. 105). Hun vedgår imidlertid at hos Stortinget var alliansemotivet nær sagt fraværende i krigens første fase (s. 106). Det samme gjaldt regjeringen, jf. kongelig resolusjon av 23.3.2011. Det blir som Afghanistan-utvalget. Ingen sa på forhånd at Norge skal gå til krig for å tekkes USA. Etterpå sies det, men det er uredelig. Skal formålet som troverdig partner stå til troverdig, og ikke bare for å pynte på en mislykket krig, må formålet ha vært uttalt på forhånd. Det er også slik folkeretten utvikles. For at praksis skal bli en rettslig norm, må normen ha vært intendert.

Knut S. Vikør beskriver detaljrikt islamistenes deltakelse i krigen. Vikør nevner at den libyske islamske kampgruppen (LIFG) tre ganger forsøkte å ta livet av Gaddafi. Etter dette ettersøkte Libya, som første stat, Osama bin Laden gjennom Interpol. Libya mente at LIFG stod i ledtog med al-Qaida. Hvorfor minimerer Vikør dette? Det store innslaget av jihadistiske libyske fremmedkrigere i Syria taler også for å framheve jihadismen blant opprørerne i Libya. Vikør kritiserer Ola Tunander for å overforenkle islamistenes rolle i krigen. Imidlertid avkrefter ikke Vikør Tunanders narrativ. Selv om Tunander ikke nyanserer mellom ulike islamske retninger, beskriver han hvordan islamistiske krefter inngikk i Vestens krigsspill. Tunander legger for dagen de mest kyniske sidene av krigen, godt dokumentert med kilder.

Antologien viser stor bredde i den viktige selvforståelsen som trengs for at Norge skal opphøre som global undertrykker. 